\title{
The Effect of Transformational Leadership and Organization Justice on Employee Time Theft in the Government Environment of Mandailing Natal Regency
}

\author{
Ismail Lubis $^{1}$, Isfenti Sadalia ${ }^{2}$, Yeni Absah ${ }^{2}$ \\ ${ }^{1,2}$ Master of Management Study Program on Postgraduate School of University of Sumatera Utara \\ Corresponding Author: Ismail Lubis
}

\begin{abstract}
Time theft is a disservice to the organization, both economically and productively. This research aims to examine the effect of transformational leadership and organizational justice on employee time theft in Mandailing Natal Regency. Sample of this research is civil servant $(\mathrm{N}=377)$ at 34 government institution in Mandailing Natal Regency. This type of research is correlational research. The method used to measure variables using self-report. Data analysis using multiple linear regression. The result showed that transformational leadership did not have a significant effect on the time theft $(\beta=-0,032 p>0,05)$, meanwhile organizational justice have a significant effect on time theft ( $\beta$ $=-0,209 \mathrm{p}<0,05)$. The negative regression coefficient value showed the direction of the negative relationship between the organizational justice and time theft, means that the higher the organizational justice felt by employees, the lower the chances of that person committing time theft. Vice versa, the lower organizational justice felt by employees, the higher the chance that person will commit time theft behavior.
\end{abstract}

Keyword: Time Theft, Transformational Leadership, Organizational Justice

\section{BACKGROUND}

Violation of working hours occurred in government agencies of Mandailing Natal Regency, North Sumatra Province. According to the data obtained based on the attendance data of morning and afternoon ceremony as well as work attendance data through electronic attendance, it is stated that approximately $10 \%-13 \%$ of employees are late or absent. Furthermore, there are employees whose cumulative number of absences in one year is more than 45 days without explanation. This case was found in several regional work units in Mandailing Natal Regency in 2018.

A construct that can explain this phenomenon is known as time theft. Time theft can be explained as an act of disciplinary action by employees at work (Kulas et al., 2007). Behaviors that describe time theft, such as arriving late for work, leaving early without notification, and not logging in without information (Hollinger \& Clark, 1983; Le Roy, Bastounis, \& Minimbas-Poussard, 2012), using the internet and social media that are not related to work during working hours (Brock, Martin \& Buckley, 2013).

Time theft in this case is a violation of the regulations regarding working hour provisions in Government Agencies. Regulations regarding working hours of government employees are regulated in Presidential Decree number 68 of 1995 concerning Working Days in Government Institutions. In this Presidential Decree number 68 of 1995, the number of effective working hours in five working days is 37.5 hours. In line with Presidential Decree number 68 of 1995, the Mandailing Natal 
Regency government has regulated a system of working days and working hours for Civil Servants through the Regulation of the Regent of Mandailing Natal No.12-2018 concerning the Implementation of an Electronic Attendance System in the Mandailing Natal Regency Government.

Until now, empirical research on time theft or the behavior of stealing working time in working hours is still very limited. This is possible due to the perception that stealing work time is a relatively minor offense compared to other types of irregularities. Whereas when a civil servant wastes working time, it will affect the poor service to the community.

There are many factors that influence time theft, including organizational factors and individual factors. Organizational factors that are situational in nature such as organizational justice or perceived injustice in organizations (Greenberg, 1990; LeRoy et al., 2012), subordinates' perceptions of leadership (Dineen, et al., 2006), resources owned by the organization (Cordes \& Dougherty, 1993). Individual factors that influence time theft include personality (Chang \& Smithikrai, 2010), work experience (Martin, Buckley, Brock, \& Ketchen, 2010), demographic characteristics such as age (Lau, Au, \& Ho, 2003), gender (Fine, Horowitz, Weigler \& Basis, 2003).

Table 1. Pre-Survey Results to determine the factors that affect time theft in The Government Environment of Mandailing Natal Regency

Factors affecting Time Theft

\begin{tabular}{|l|l|l|}
\hline Factors affecting Time Theft & Responses & \% \\
\hline Organizational justice & 9 & 45 \\
\hline Transformational leadership & 7 & 35 \\
\hline Co-workers & 2 & 10 \\
\hline Facilities & 2 & 10 \\
\hline Total & 20 & 100 \\
\hline
\end{tabular}

From Table 1 it can be seen that organizational justice $(45 \%)$ and transformational leadership (35\%) are the two factors that have the highest percentage, followed by co-worker variables (10\%) and facilities / means of supporting work implementation (10\%).

Transformational leaders are a type of leader who can effectively mobilize subordinates (Avolio \& Yammarino, 2002). The transformation leader has 4 (four) components, namely idealized influence, the leader as a role model that makes his subordinates respect and admire; inspirational motivation, leaders set high standards of work behavior and become a reference for their subordinates so as to provide challenges and opportunities for their subordinates to work better; intellectual stimulation, leaders provide opportunities for their subordinates to be more critical and innovative; The leader's individual consideration understands the unique needs of each of his subordinates.

Another situational factor that will be examined in relation to time theft in this study is organizational justice. Organizational Justice is employees' perceptions of justice received in the workplace or perceptions of whether employees are treated fairly at work (Fox, Spector, \& Miles, 2001). Two concepts of organizational justice that are often studied are distributive justice and procedural justice (Fox, Spector, \& Miles, 2001). Distributive justice is related to the fair perception of employees regarding the final results received compared to the contributions that have been given to the organization, while procedural justice is related to the perception of fairness regarding the procedures or policies applied to get the results received (Folger \& Greenberg, 1985; Leventhal, Karusa , \& Fry, 1980).

Based on these reasons, the researcher wants to see the relationship between transformational leadership and organizational justice on the behavior of time theft among civil servants in Indonesia. This is also based on the cultural values put forward by Hofstede (1991) that Asian countries, including Indonesia, have a high power distance, where in the context of work there is a dependency of subordinates on their leaders (Hofstede, 1991). 
Dynamics of Relationship between

Transformational Leadership and Attitudes toward Time Theft.

Transformational leaders provide opportunities for their subordinates to perform challenging tasks that will stimulate the growth and psychological development of their subordinates (intellectual stimulation) and provide assignments according to the needs and abilities of their subordinates (individual consideration). This will lead to job satisfaction. If employee satisfaction is high, then their attitude will be negative towards time theft, or they will not waste time working in the office.

On the other hand, a weak employee's perception of their leader as a transformational leader will affect the employee's time theft attitude. Leaders who are non-transformational (such as passive / ineffective leadership) are perceived to be ineffective because the leader cannot convince his subordinates to feel that the task in his job is his own, cannot convey clear expectations (This condition cannot meet employee job satisfaction. Unfulfilled employee work will allow employees to have a positive attitude towards time theft. Non-transformational leaders (such as closed leadership) are perceived to be ineffective because the leader is closed to new ideas, they even refuse input for various reasons and are afraid to take risks.

\section{Dynamics of Relationship between Organizational Justice and Attitudes toward Time Theft.}

Treatment experienced by individuals in the organization will be seen as fair and unfair experiences. Employees will display positive behavior when they receive rewards according to what they have given to the organization (Organ, 1988). Employees who have a perception of fairness in the workplace can increase employee job satisfaction (Fischer, 2004), increase organizational commitment (Sweeney \& McFarlin, 1992), improve performance and reduce conflict (Cropanzano, Bowen \& Gilliland, 2007), and increase trust in leaders (Tyler \& Lind, 1988). If employees see that the policies made by the organization are correct and fair, then these employees tend to feel satisfied and will behave in accordance with organizational rules (Fischer, 2004).

\section{Conceptual framework}

Transformational leaders can make their subordinates have meaning for their work, provide opportunities for their subordinates to perform challenging tasks and according to the needs and abilities of their subordinates. This will lead to job satisfaction. If employee job satisfaction is high, employees will have a negative attitude towards time theft, so that employees will not waste time working in the office. The second variable is organizational justice as employees' perceptions of justice in organizations that can provide satisfaction at work so this has a negative effect on time theft.



Figure 1. Research Concept Framework 


\section{RESEARCH METHODS}

This research is classified as an explanatory research, which aims to determine the extent of the influence of one variable on other variables of a population without manipulating the variables (Kerlinger \& Lee, 1999). This research uses quantitative methods. The quantitative method used in this research is nonexperimental quantitative research, namely survey research by distributing questionnaires to the individuals who are the sample (Cozby \& Bates, 2012). The design used in this study is a cross sectional study where data collection is carried out at one time and is not sustainable (Gravetter \& Forzano, 2012). The population in this study were all Civil Servants in the Mandailing Natal Regency Government which until December 2018 amounted to 6,554 people with a sample size of 377 people. Collecting data using a questionnaire and tested using SPSS.2.1 software.

\section{RESEARCH RESULTS \& DISCUSSION Regression Analysis $\left(\mathbf{R}^{2}\right)$}

Table 2: Regression Analysis Summary Model

\begin{tabular}{|c|c|c|c|c|c|c|c|c|c|}
\hline \multirow[t]{2}{*}{ Model } & \multirow[t]{2}{*}{$\mathbf{R}$} & \multirow{2}{*}{$\begin{array}{l}\text { R } \\
\text { Square }\end{array}$} & \multirow{2}{*}{$\begin{array}{l}\text { Adjusted } \\
\text { Square }\end{array}$} & \multirow{2}{*}{$\begin{array}{l}\text { Std. Error of the } \\
\text { Estimate }\end{array}$} & \multicolumn{5}{|l|}{ Change Statistics } \\
\hline & & & & & $\begin{array}{l}\text { R Square } \\
\text { Change }\end{array}$ & $\begin{array}{l}\text { F } \\
\text { Change }\end{array}$ & df1 & df2 & $\begin{array}{ll}\text { Sig. } & \text { F } \\
\text { Change } & \\
\end{array}$ \\
\hline 1 &, $269^{\mathrm{a}}$ &, 072 & ,060 & 8,12723 &, 072 & 5,720 & 5 & 367 &, 000 \\
\hline 2 &, $337^{b}$ &, 113 & ,096 & 7,96733 &, 041 & 8,440 & 2 & 365 &, 000 \\
\hline \multicolumn{10}{|c|}{ a. Predictors: (Constant), Position, Gender, Education Level, Working Period, Age } \\
\hline \multicolumn{10}{|c|}{ b. Predictors: (Constant), Position, Gender, Education Level, Working Period, Age, leadership, justice } \\
\hline \multicolumn{10}{|c|}{ c. Dependent Variable: time_theft } \\
\hline
\end{tabular}

$\mathrm{R}^{2}$ value in the first stage model is 0.072 or $7.2 \%$. This means that the proportion of the variance of the time theft variable which can be explained by demographic variables such as age, gender, position, years of service, and education level is $7.2 \%$. Meanwhile, the other $92.8 \%$ are influenced by other variables. Then, in the second stage model, the $\mathrm{R} 2$ results are
0.113 or $11.3 \%$. That is, the proportion of the variance of the time theft variable which can be explained by the variables of age, gender, position, tenure, education level, transformational leadership and organizational justice together is $11.3 \%$, while the other $88.7 \%$ is influenced by variables. other.

Table 3: Anova table

\begin{tabular}{|c|c|c|c|c|c|c|}
\hline \multicolumn{2}{|c|}{ Model } & Sum of Squares & Df & Mean Square & $\mathbf{F}$ & Sig. \\
\hline \multirow[t]{3}{*}{1} & Regression & 1889,214 & 5 & 377,843 & 5,720 & $.000^{\mathrm{b}}$ \\
\hline & Residual & 24241,039 & 367 & 66,052 & & \\
\hline & Total & 26130,252 & 372 & & & \\
\hline \multirow[t]{3}{*}{2} & Regression & 2960,674 & 7 & 422,953 & 6,663 & $.000^{\mathrm{c}}$ \\
\hline & Residual & 23169,578 & 365 & 63,478 & & \\
\hline & Total & 26130,252 & 372 & & & \\
\hline \multicolumn{7}{|c|}{ a. Predictors: (Constant), Position, Gender, Education Level, Working Period, Age } \\
\hline \multicolumn{7}{|c|}{ b. Predictors: (Constant), Position, Gender, Education Level, Working Period, Age, leadership, justice } \\
\hline \multicolumn{7}{|c|}{ c. Dependent Variable: time_theft } \\
\hline
\end{tabular}

Based on Table 4.5 in model 2, it is obtained a significance value (sig.) Of 0,000 , this means that the sig value. $<0.05$, so the null hypothesis $(\mathrm{H} 0)$ which states that there is no significant effect of the transformational leadership and organizational justice variables on time theft is rejected. That is, there is a significant effect of transformational leadership and organizational justice on the variable time theft.

The level of the regression coefficient of each independent variable. The resulting regression coefficient is significant or not can be seen in the sig column. (sixth column). If the value is sig. 
$<0.05$, the resulting regression coefficient has a significant effect on the time theft variable. The following is a table of the regression coefficients for each independent variable on the time theft variable:

Table 4: Regression Coefficient

\begin{tabular}{|c|c|c|c|c|c|c|}
\hline \multicolumn{2}{|c|}{ Model } & \multicolumn{2}{|c|}{ Unstandardized Coefficients } & \multirow{2}{*}{$\begin{array}{l}\text { Standardized Coefficients } \\
\text { Beta }\end{array}$} & \multirow{2}{*}{$\begin{array}{l}\boldsymbol{T} \\
11,891\end{array}$} & \multirow{2}{*}{$\begin{array}{l}\text { Sig. } \\
, 000\end{array}$} \\
\hline 1 & (Constant) & $\begin{array}{l}\boldsymbol{B} \\
52,856\end{array}$ & $\begin{array}{l}\text { Std. Error } \\
4,445\end{array}$ & & & \\
\hline & Age &,- 271 &, 086 &,- 303 & $-3,161$ & ,002 \\
\hline & Gender & ,372 & ,869 &, 022 &, 428 & ,669 \\
\hline & Level of education &, 356 &, 584 & 033 & 610 &, 542 \\
\hline & Years of service & , 156 & ,094 &, 154 & 1,650 &, 100 \\
\hline & Position & 1,381 & 677 &, 125 & 2,040 & ,042 \\
\hline 2 & (Constant) & 65,816 & 5,597 & & 11,760 &, 000 \\
\hline & Age &,- 269 & ,084 &,- 301 & $-3,198$ &, 002 \\
\hline & Gender & 541 & ,853 & ,032 & ,635 &, 526 \\
\hline & Level of education & ,284 &, 573 &, 026 & ,497 &, 620 \\
\hline & Years of service & , 159 &, 093 & ,157 & 1,712 &, 088 \\
\hline & Position & 1,142 & ,667 &, 103 & 1,711 & ,088 \\
\hline & Leadership &,- 032 & ,047 &,- 034 &,- 689 &, 491 \\
\hline & Justice &,- 209 &, 053 &,- 198 & $-3,964$ &, 000 \\
\hline
\end{tabular}

Based on the table of unstandardized coefficients (B) in model 2 above, now the regression equation is obtained as follows: $y=a+b 1 . x 1+b 2 . x 2+b 2 . x 2+b 3 . x 3+$ b4.x4 + b5.x5 + b6.x6 + b7.x7

Time theft $=65,816-0.269($ Age $)+0.541$ $($ Gender $)+0.284$ (Education level $)+0.159$ (Service period) +1.142 (Position) -0.032 (Transformational leadership) - 0.209 (Organizational Justice)

From the regression equation above, it can be explained that of the seven independent variables only age and organizational justice have a significant effect. The explanation of the regression coefficient value obtained by each independent variable is as follows:

1. The age variable. Obtained the value of the regression coefficient (b1) of -0.269 with a sig value. of 0.002 (Sig. <0.05). Thus, the null hypothesis (H01) which states that there is no significant effect of the age variable on the time theft variable is rejected. This means that the age variable has a significant effect on the time theft variable.

2. Gender variable. Obtained the value of the regression coefficient (b2) of 0.541 with a sig. amounting to 0.526 (Sig.> 0.05). Thus, the null hypothesis (H02) which states there is no significant effect of the gender variable on the time theft variable is accepted. This means that the gender variable does not have a significant effect on the time theft variable.

3. The variable level of education. Obtained the value of the regression coefficient (b3) of 0.284 with a sig value. of 0.620 (Sig.> 0.05). Thus, the null hypothesis (H03) which states that there is no significant effect of the education level variable on the time theft variable is accepted. This means that the education level variable does not have a significant effect on the time theft variable.

4. Variable years of service. Obtained the value of the regression coefficient (b4) of 0.159 with a sig. amounting to 0.088 (Sig.> 0.05). Thus, the null hypothesis (H04) which states that there is no significant effect of the tenure variable on the time theft variable is accepted. This means that the tenure variable does not have a significant effect on the time theft variable.

5. Position variable. Obtained the value of the regression coefficient (b5) of 1.142 with a sig value. amounting to 0.088 (Sig.> 0.05). Thus, the null hypothesis (H05) which states that there is no 
significant effect of the position variable on the time theft variable is accepted. This means that the position variable does not have a significant effect on the time theft variable.

6. Transformational leadership variables. Obtained the value of the regression coefficient (b6) of -0.032 with a sig value. of 0.491 (Sig.> 0.05). Thus, the null hypothesis (H06) which states that there is no significant effect of the transformational leadership variable on the time theft variable is accepted. This means that the transformational leadership variable does not have a significant effect on the time theft variable.

7. Variable organizational justice. Obtained the value of the regression coefficient (b7) of -0.209 with a sig value. of 0.000 (Sig. <0.05). Thus the null hypothesis (H07) which states that there is no significant effect of the organizational justice variable on the time theft variable is rejected. This means that the organizational justice variable has a significant effect on the time theft variable.

\section{The Effect of Age Variables on Time Theft}

Age variable partially has a significant effect on time theft. This is consistent with the results of research by Lau et al. (2003) that demographic characteristics such as age have an effect on time theft. In the results of this study, the negative regression coefficient indicates the direction of the negative relationship between the age variable and the time theft variable. This means that the older an employee is, the lower the chance that person will commit time theft. Conversely, the younger the employee, the higher the chance that person will commit time theft.

\section{Effect of Gender Variable on Time Theft}

Gender variable partially does not have a significant effect on time theft. This is not in line with the results of the study by
Fine et al. (2003) who stated that demographic characteristics such as gender have an effect on time theft

\section{The Effect of Educational Level Variables on Time Theft}

The variable level of education partially does not have a significant effect on time theft. This is not in accordance with the research results of Butt, Tatlah, Rehman \& Azam (2019) which found that education has an effect on time theft in lecturers who teach in higher education.

\section{The Influence of Working Period Variables on Time Theft}

The working period variable partially does not have a significant effect on time theft. This is not in accordance with the results of research by Henle et al. (2010) where employees who have worked for 1 (one) year to 2 (two) years still commit time theft and research by Martin et al. (2013) which states that tenure has an effect on time theft.

\section{The Influence of Position Variables on Time Theft}

The job variable partially does not have a significant effect on time theft. This is not in accordance with the results of research by Huiras \& Morris (2000) which states that a person's position in the organization affects time theft, employees who do not have a position tend to commit time theft.

\section{The Influence of Transformational Leadership Variables on Time Theft \\ The transformational leadership variable partially does not have a significant effect on time theft. The results of this study are inconsistent with the results of research conducted by Dineen et al. (2006), where the integrity of a leader can reduce the tendency of employees to commit time theft.}




\section{The Influence of Variable Organizational Justice on Time Theft}

Organizationl justice variable partially has a significant effect on time theft. The results of this study are consistent with the results of research by Francis \& Barling (2005). The negative regression coefficient values found in this study indicate the direction of the negative relationship between the organizational justice variable and the time theft variable. This means that the higher the organizational justice perceived by the employee, the lower the chance that person will commit time theft behavior. And vice versa, the lower organizational justice felt by employees, the higher the chance that person will commit time theft behavior.

\section{CONCLUSION}

This study aims to determine whether there is an effect of transformational leadership and organizational justice on time theft in employees, when demographic variables such as age, gender, education level, years of service, and position are statistically controlled. The results showed that the transformational leadership variable did not have a significant effect on employee time theft. While the second independent variable, namely organizational justice has a significant effect on employee time theft. The results of the analysis show that the organizational justice variable has a negative effect on employee time theft. This indicates that the more an employee feels treated fairly by the organization, the lower the chance for an employee to commit time theft. Vice versa, the more an employee feels unfairly treated by the organization, the higher the chance the employee will commit time theft.

\section{Acknowledgement: None}

\section{Conflict of Interest: None}

Source of Funding: None

\section{REFERENCES}

1. Adam, J.S. (1963). Toward an understanding of Inequity. Journal of Abnormal and Social Psychology. 67: 422436.

2. Alder, G.S.,, Schminke, M., Noel, T.W., \& Kuenzi, M. (2008). Employee reactions to Internet monitoring: The mediating role of ethical orientation. Journal of Business Ethics, 80, 481-498.

3. Alexander, S., and Ruderman, M. (1987). The role of procedural and distributive justice in organizational behavior. Social Justice Research. 1: 177-198.

4. Applebaum, S. H., Deguire, K. J., \& Lay, M. (2005). The relationship of ethical climate to deviant workplace behavior. Corporate Governance. 5: 43-55.

5. Avolio, B. J., and Yammarino, F. J. (2002). Transformational and charismatic leadership: The road ahead. Oxford, UK: Elsevier Science. Retrieved from: https://books.google.co.id/books

6. Bass, B. M. (1999). Two decades of research and development in transformational leadership. European Journal of Work and Organizational Psychology. 8: 9-32.

7. Becker, T. E., Randall D. M., and Riegel, C. D. (1995). The Multidimensional View of Commitment and the Theory of Reasoned Action: A Comparative Evaluation. Journal of Management. 21: 617-638.

8. Bennett, R. J. and S. L.Robinson: 2003, 'The Past, Present and Future of Deviance Research', in J. Greenberg (ed.), Organizational Behavior: The State of the Science (Lawrence Erlbaum, Mahwah, NJ), pp. 247-281.

9. Badan Kepegawaian Nasional: SIARAN PERS 2018. Diunduh pada Agustus 2018, dari www.bkn.go.id/wpcontent/uploads/2018/02/7

10. Bies, R. J., and Moag, J.F (1986). Interactional Justice: Communication criteria of fairness. In R. J.

11. Bordia, P.S., Restubog, L.D., and Tang, R.L. (2008). When employees strike back: Investigating mediating mechanisms between psychological contract breach and workplace deviance. Journal of Applied Psychology, 93: 1104.

12. Brockner, J., and Wiensefeld, B.M. (1996). An integrative framework for explaining attractiveness of decisions: the interactive 
effect of outcomes and proceses. Psychological Bulletin. 120: 189-208.

13. Brock, M.E, Martin, L.E \& Buckley, M.R. ( 2013). Time Theft in Organizations: The Development of the Time Banditry Questionnaire. International Journal of Selection and Assesment.

14. Campbell, J. P. and Campbell, R. J. 1990. Productivity in Organizations. Oxford : Joshey Bass Publisher.

15. Carless, S. A., Wearing, A. J., and Mann, L. (2000). A short measure of transformational leadership. Journal of Business and Psychology. 14: 389-405.

16. Cozby, Paul C. and Bates, Scott C. (2012). Methods in Behavioral Research (11 ${ }^{\text {th }}$ Ed.). New York : The McGraw-Hill Companies,Inc.

17. C.D Beugre. (2002) Understanding organizational justice and its impact on managing employess: An African perspective, The International Journal of Human Resource Management.

18. Colbert, A.E., Mount, M.K., Harter, J. K., Witt, L.A., and Barrick, M. R (2004). Interactive effect of personality and perceptions of the work situation on workplace deviance. Jornal of Applied Psychology. 89: 599-609.

19. Cordes, C.L., \& Dougherty, T.W (1993). A review and an integration of research on job burnout. The Academy of Managemen Review, 18(4), 621-656

20. Cropanzano, R., Bowen, D.E. and Gilliland, S.W., (2007), The Management of Organizational Justice. Academy of Management Prspectives.

21. Crosby, F. (1976). A Model of egoistical relative deprivation. Psychological Review. 83: 85-113

22. Daft, R. (2010). Organization theory and design $\left(10^{\text {th }}\right.$ ed). USA : Cengage learning.

23. De Boer, EM, Bakker, A.B., Syroit, J. E and Schaufeli, W.B. (2002), "Unfairness at work as a predictor of absenteeism", Journal of Organizational Behavior. 23: 181-197

24. Deutsch, M. (1975). Equity, equality, and need: What determines which value will be used as basis of distributive justice?. Journal of Social Issues. 31: 137-149.

25. Erdogu Murat, (2018). Effect of Organizational Justice Behavior on Organizational Silece and Cynicism: A
Research on Academic from Schools of Physical Education and Sports.

26. Elovainio, M., Kivimaki, M., and Vahtera, J. Organizational Justice: Evidence of New Psychosocial Predictor of Health.

27. Davis, A. L., and Rothstein, H. R. (2006). The Effects ofthe Perceived Behavioral Integrity of Managers on Employee Attitudes: A Meta- Analysis. Journal of Business Ethics. 67: 407-419.

28. Field, A. (2013). Discovering statistics using IBM SPSS Statistics ( $4^{\text {th }}$ ed.). Washington DC: SAGE.

29. Fine, S., Horowitz, I., Weigler, H., \& Basis, L. (2010). Is good character good enough? The effects of situational variables on the relationship between integrity and counterproductive work behaviors. Human Resource Management Review, 20(1), 7384.

30. Fischer, R. (2004). Rewarding employee loyalty: An Organizational justice approach. International Journal of Organizational Behavior. 8: 486-503.

31. Folger, R., and Konovsky,M.A (1989). Effect of procedural and distributive justice on reactions to pay raise decisions. Academy of Management Journal, 32: 115130

32. Fox, S., Spector, P.E., and Miles, D. (2001). Counterproductive work behavior $(\mathrm{CWB})$ in response to job stressors and organizational justice: Some mediator and moderator terstes for autonomy and emotions. Journal of Vocational Behavior. 59: 291-309.

33. Folger, R., and Greenberg,J. (1985). Procedural justice: An interpretive analysis of personnel systems. In K.M. Rowland \& G.R Ferris (Eds.), Research in personnel and human resource management (Vol.3, pp. 141-183). Greenwich, CT: JAI Press

34. Francis L. and Barling, J. (2005). Organizational injustice and psychological strain. Canadian Journal of Behavioral Sciences. 37: 250-261.

35. Ghozali, I. (2018). Aplikasi Analisis Multivariete SPSS 25 (9th ed.). Semarang: Universitas Diponegoro.

36. Gravetter, F. J. and Forzano, L. A. B. (2012). Research methods for the behavioral sciences $4^{\text {th }}$ edition. USA.Wadsworth.

37. Greenberg, J. (1990). Employee theft as a reaction to underpayment inequity: the 
hiddencost of pay cuts. Journal of Applied Psychology. 75: 561-568.

38. Greenberg, L. and Barling, J. (1996). Employee theft. dalam C. L. Cooper, \& D. M. Rousseau (Eds.), Trends in organizational behavior. 1: 49-64. New York: Wiley.

39. Greenberg, J.: 2002, 'Who Stole the Money and When? Individual and Situational Determinants of Employee Theft', Organizational Behavior and Human Decision Processes 89, 985-1003.

40. Gurbuz S. and Mert I.S., (2009). Validity and Reliability Testing of Organizational Justice Scale: An Empirical Study in a Public Organization.

41. Henle, C. A., Reeve, C. L., and Pitts, V. E. (2010). Stealing time at work: Attitude, social pressure, and perceived control as predictors of time theft, Journal of Business Ethics. 94: 53-67

42. Hollinger, R. D., and Clark, J. P. (1983). Theft by employees. Lexington, MA: Lexington Books

43. Hofstede, G. (1991). Cultures and organizations. Intercultural cooperation and its importance for survival. Software of the mind. London: Mc Iraw-Hill. Retrieved from : libgen.io

44. Hulin, C.L (1991). Adaptation, persistence and commitment in organizations. In M.D. Dunnete \& L.M Hough (Eds), Handbook of industrial and organizational psychology ( $2^{\text {nd }}$ ed.; vol. 2 pp. 445-506). Palo Alto, CA: Consulting Psychologist Press.

45. Jermier, J.M., Knight, D., and Nord, W. (1994). Resistance and power in organizations, London: Roudledge.

46. Kerlinger, F. N. and Lee, H. B. (1999). Foundations of behavioral research. $\left(4^{\text {th }}\right.$ edition). San Diego : Harcourt College Publisher.

47. Kulas, J. T., McInnerney, J. E., Demuth, R. and Jawinski, V. (2007). Employee satisfaction and theft: testing climate perceptions as a mediator. Journal of Psychology. 141: 389- 402.

48. Lau, V. C., Au, W. T. and Ho, J. M. (2003). A qualitative and quantitative review of antecedents of counterproductive behavior in organizations. Journal of Business and Psychology. 18: 73-99.

49. Leventhal, G.S., Karuza, J. and Fry, W.R. (1980). Beyond fairness: A theory of allocation preferences. In G. Mikula (Ed), Justice and social ineraction (pp.167-218). New York: Springer-Verlag.

50. Leroy, H., Palanski, Y., and Simons, T. (2012). Authentic leadership and behavioral integrity as drivers of follower commitment and performance. Journal of Business Ethics. 107: 255-264.

51. Lewicki, B.H.Sheppard, and M.H. Bazerman (Eds.), Research on negotiation in organizations (Vol. 1, pp. 43-55). Greenwich, CT: JAI Press.

52. Liu Yan, Berry C.M (2013). Identity, Moral, and Equity Perspectives on the Relationship Between Experinced Injustice and Time Theft. Journal Business Ethics. 118: 73-83.

53. Malachowski, D. (2005). Wasted time at work costing companies billions. Retrieved on July 28, 2008, from http://sfgate.com/cgi-

bin/article.cgi? $\mathrm{f}=/ \mathrm{g} / \mathrm{a} / 2005 / 07 / 11 /$

wastingtime.TMP

54. Masterson, S. S., Lewis, K., Goldman, B. M., and Taylor , M. S. (2000). Integrating justice and social exchange: the differing effects of fair procedures and treatment on work relationships. Acad. Manage. J. 43, 738-748. doi:10.2307/1556364

55. Moorman, R.H. (1991). Relationship between organizational justice and organizational citizenship behaviors: Do fairness perceptions influence employee citizenship? Journal of Applied Psychology. 76: 845-855.

56. O’Leary-Kelly, A., Griffin, R. W., \& Glew, D.J (1996). Organization Motivated Agression: A research frame work. Academy of Management Review, 21, 225253.

57. Perry, J.L., \& Wise, L.R. (1990). The motivational bases of public servive. Public Administration Review. 75: 53-78.

58. Pfeffer, J., and Langton, N. (1993). The effects of wage dispersion on satisfaction, productivity, and working collaboratively: Evidence from college and universiy faculty. Administrative Science Quarterly. 38: 382-407.

59. Podsakoff, P. M., MacKenzie, S. B., Moorman, R. H., and Fetter, R. (1990). Transformational leader behaviors and their effects on followers' trust in leader, satisfaction, and organizational citizenship behaviors. The leadership quarterly. 1: 107142. 
60. Rainey, H. G., and Steinbauer, P. (1999). Galloping elephants: Developing elements of a theory of effective government organizations. Journal of public administration research and theory. 9:1-32.

61. Robbins, Stephen P., Judge, Timothy A.. (2013). Organizational Behavior (Ed. 15 ${ }^{\text {th }}$ ) .USA : Pearson Education, Inc.

62. Shin, S. J., and Zhou, J. (2003). Transformational leadership, conservation, and creativity: Evidence from Korea. Academy of management Journal. 46: 703714.

63. Simons, T. L. (1999) Behavioral integrity as a criticalingredient for transformational leadership', Journal of Organizational Change Management 12: 89-104.

64. Spector, P.E., Fox,S., Penney, L. M., Bruursema, K., Goh, A., \& Kessler, S. (2006). The dimensionality of counterproductivity: Are all counterproductive behaviors created equal?Journal of Vocational 68, 446-460.

65. Suresh, Sharma (2014). Nursing Research and Statistics. Elsevier Health Sciences. P.224. ISBN 9788131237861.

66. Sweeney, P.D, McFarlin, D.B. (1993). Workers' evaluations of the ends and the means: an examination of four models of distributive and procedural justice",
Organizational Behavior and Human Decision Processes. 55: 23-40.

67. Tang, T. L. and Y. Chen: 2008, 'Intelligence vs. Wisdom: The Love of Money, Machiavellianism, and Unethical Behavior across College Major and Gender', Journal of Business Ethics 82, 1-26.

68. Tyler, T. R., and Bies, R. J (1990). Beyond Formal Procedures: The Interpersonal context of procedural justice. In J.S. Carroll (Ed.), Applied social psychology and organizational settings (pp. 77-98). Hillsdale, N.J:Erlbaum

69. Weaver, G. R., L. K. Treviñ and P. L. Cochran: 1999, Corporate Ethics Programs as Control Systems: Influences of Executive Commitment and Environmental Factors', Academy of Management Journal 42, 4157.

70. Yukl, Gary (2010). Leadership in Organization (Seventh Edition). USA : Pearson Education,Inc.

How to cite this article: Lubis I, Sadalia I, Absah Y. The effect of transformational leadership and organization justice on employee time theft in the government environment of Mandailing Natal Regency. International Journal of Research and Review. 2021; 8(4): 376-385. DOI: https://doi.org/10.52403/ijrr. 20210444 